\title{
Expression of BvGLP-1 Encoding a Germin-Like Protein from Sugar Beet in Arabidopsis thaliana Leads to Resistance Against Phytopathogenic Fungi
}

\author{
Katrin Knecht, ${ }^{1}$ Monique Seyffarth, ${ }^{2}$ Christine Desel, ${ }^{3}$ Tim Thurau, ${ }^{1}$ Irena Sherameti, ${ }^{2}$ Binggan Lou, ${ }^{4}$ \\ Ralf Oelmüller, ${ }^{2}$ and Daguang Cai ${ }^{1}$ \\ ${ }^{1}$ Department of Molecular Phytopathology, Institute of Phytopathology Christian-Albrechts-University of Kiel, \\ Hermann-Rodewald Str. 9, D-24118 Kiel, Germany; ${ }^{2}$ Institute of Plant Physiology, Friedrich-Schiller-University Jena, \\ Dornburger Str. 159, D-07743 Jena, Germany; ${ }^{3}$ Institute of Botany, Christian-Albrechts-University of Kiel, Olshausenstr. 40, \\ D-24118 Kiel, Germany; ${ }^{4}$ Institute of Phytopathology, Zhejiang University, Hangzhou 310029, China
}

Submitted 10 July 2009. Accepted 20 November 2009.

\begin{abstract}
Nematode (Heterodera schachtii) resistance in sugar beet (Beta vulgaris) is controlled by a single dominant resistance gene, $\mathrm{Hs}^{\text {pro-1 }}$. BvGLP-1 was cloned from resistant sugar beet. The $B v G L P-1$ messenger $(\mathrm{m}) \mathrm{RNA}$ is highly upregulated in the resistant plants after nematode infection, suggesting its role in the $\mathrm{Hs}^{\text {pro-l }}$ mediated resistance. BvGLP1 exhibits sequence homology to a set of plant germin-like proteins (GLP), from which several have proved to be functional in plant basal or defense resistance against fungal pathogens. To test whether BvGLP-1 is also involved in the plant-fungus interaction, we transferred $B v G L P-1$ into Arabidopsis and challenged the transgenic plants with the pathogenic fungi Verticillium longisporum and Rhizoctonia solani as well as with the beneficial endophytic fungus Piriformospora indica. The expression of $B v G L P-1$ in Arabidopsis elevated the $\mathrm{H}_{2} \mathrm{O}_{2}$ content and conferred significant resistance to $V$. longisporum and $R$. solani but did not affect the beneficial interaction with $P$. indica in seedlings. Microscopic observations revealed a dramatic reduction in the amount of hyphae of the pathogenic fungi on the root surface as well as of fungal mycelium developed inside the roots of transgenic Arabidopsis compared with wild-type plants. Molecular analysis demonstrated that the BvGLP-1 expression in Arabidopsis constitutively activates the expression of a subset of plant defense-related proteins such as PR-1 to PR-4 and PDF1.2 but not PDF2.1 and PDF2.3. In contrast, the PDF 2.1 mRNA level was downregulated. These data suggest an important role of BvGLP-1 in establishment of plant defense responses, which follow specific signaling routes that diverge from those induced by the beneficial fungus.
\end{abstract}

Plant genomes encode a subgroup of cupins called germin and germin-like proteins (GLP): water-soluble, protease-resistant, heat-stable, and sodium dodecyl sulfate-tolerant glycoproteins (Lane 1994; Woo et al. 2000), which assemble into homohexameric complexes in vivo (Zhang et al. 1995; Vallelian et al. 1998; Christensen et al. 2004). Several members of the germin family contain enzymes with oxalate oxidase $(\mathrm{OxO})$ or superoxide dismutase (SOD) activities leading to hydrogen

Corresponding author: D. Cai; Telephone: +49-431-8803215; Fax: +49431-8801583; E-mail: dcai@ phytomed.uni-kiel.de peroxide $\left(\mathrm{H}_{2} \mathrm{O}_{2}\right)$ production (Chiriboga 1966; Lane 1994; Zimmermann et al. 2006). In barley, six GLP subfamilies with 21 genes have been described (HvGER1 to 6), from which only HvGER1a proved to have OxO activity whereas HvGER4d and HvGER5a both showed SOD activity, and no any enzymatic activity could be detected from HvGER2a as well as from HvGER6a (Zimmermann et al. 2006). The Arabidopsis genome contains at least 12 unique GLP genes with diverse expression patterns. Of these, at least six are gene orthologs of barley (Druka et al. 2002; Wu et al. 2000) and rice. Thus far, no enzymatic activity has been reported from Arabidopsis GLP (Carter and Thornburgh 1999; Membré et al. 2000).

GLP have been proposed to play an important role in several aspects of plant development or stress tolerance and received considerable attention for their possible contribution to plant basal host resistance. GLP-encoding genes were found to be expressed differentially in various plant tissues and the expression pattern changed from developmental to conditional. Several genes were highly induced by fungal pathogen attack (Schweizer et al. 1999; Christensen et al. 2004; Zimmermann et al. 2006). It has been proposed that, through the generation of $\mathrm{H}_{2} \mathrm{O}_{2}$ due to their OxO or SOD activity, GLP may function as a cofactor for reinforcement of the cell wall by cross-linking of plant cell wall proteins in papillae at the infection site (Olson and Varner 1993; Thordal-Christensen et al. 1997; Wei et al. 1998), and as a signaling molecule inducing a range of defense responses in a direct or indirect manner (Lane 1994; Zhou et al. 1998). Transgenic plants ectopically expressing GLP-encoding genes have provided direct evidence for a defense role of GLP. Soybean, tobacco, sunflower, and rapeseed plants transformed with a wheat GLP with OxO activity showed enhanced resistance to Sclerotinia sclerotiorum (Zaghmout et al. 1997; Donaldson et al. 2001; Hu et al. 2003; Dong et al. 2008). Poplar and corn expressing the same gene were more resistant to Septoria musiva (Liang et al. 2001) and insect predation (Ramputh et al. 2002), respectively. On the other hand, the SOD activity of HvGER5a has been demonstrated to be required for resistance-enhancing activity (Zimmermann et al. 2006). Furthermore, epidermal barley cells transiently overexpressing barley GLP or transiently silenced for HvGER3 or HvGER5 all showed more resistance against Blumeria graminis, thus suggesting their crucial role in fine regulation of plant basal resistance against fungal pathogens (Schweizer et al. 1999; Christensen et al. 2004; Zimmermann et al. 2006). 
Hs $1^{\text {pro-1 }}$ confers nematode (Heterodera schachtii) resistance in sugar beet (Beta vulgaris) (Cai et al. 1997, 2005; Thurau 2003). Several candidate genes involved in the resistance have been cloned from the resistant sugar beet (Samuelian et al. 2004). The gene BvGLP-1 (AY243465) is highly upregulated in the resistant plants by nematode infection. BvGLP-1 exhibits sequence homology to a set of plant GLP, including the Arabidopsis GLP3 (AT5G20630) as well as the barley GLP HvGER2a (DQ647620) with 43 and 42\% amino acid identity, respectively. To test the possible role of BvGLP-1 in the plantfungus interaction, we transferred BvGLP-1 into Arabidopsis and challenged the transgenic plants with two pathogenic fungi, Verticillium longisporum and Rhizoctonia solani as well as with a beneficial endophytic fungus Piriformospora indica.

The $R$. solani complex and Verticillium spp. represent two economically important groups of soilborne pathogens with a great diversity of host plants, including sugar beet and oilseed rape. $R$. solani infects primarily roots and stems of host plants (Keijer et al. 1997). Within the cortex, the rapid hyphal growth ultimately results in the collapse of the infected plants whereas Verticillium spp. invade the vascular system of the host plants through the root and systemically spread by conidia during the vegetation period (Zeise and Tiedemann 2002). The endophytic fungus $P$. indica colonizes roots of many plant species, including Arabidopsis, resulting in an increase in the biomass of roots and shoots (Varma et al. 1999; Peskan-Berghöfer et al. 2004). The beneficial fungus promotes nutrient uptake; allows plants to survive under water and salt stress; confers resistance to toxins, heavy metal ions, and pathogenic organisms; and stimulates seed production (Oelmüller et al. 2005).

Furthermore, both $R$. solani and Verticillium spp. as well as P. indica infect Arabidopsis plants (Keijer et al. 1997; Steventon et al. 2001; Veronese et al. 2003). Sugar beet is a recalcitrant crop species for transformation. Generation of transgenic sugar beet is still extremely labor intensive and time consuming. Therefore, Arabidopsis has been used as a model plant for studying sugar beet genes in regard to their role in plant-parasite interaction in our laboratory and worldwide (Thurau et al. 2003; Cai et al. 2005). Thus, transgenic Arabidopsis expressing $B v G L P-1$ provides us unique tools for studying the function of the gene $B v G L P-1$ and underlying molecular mechanisms.

In response to microbes, two distinct types of resistance are induced systemically throughout the plant: systemic acquired resistance (SAR) (Ross 1961) and induced systemic resistance (ISR) (Kloepper et al. 1992). Whereas SAR is induced by an infection with a necrotizing pathogen, ISR follows the colonization of the rhizosphere with selected nonpathogenic plant growth-promoting rhizobacteria (PGPR) (Pieterse et al. 1996). PGPR are present in large numbers on the root surface and protect plants from pathogen infection through induction of systemic resistance but without provoking any symptoms themselves. Specific recognition between protective ISRinducing rhizobacteria and the plant activates the signaling cascade leading to ISR. The downstream signaling events in the rhizobacteria-mediated ISR pathway differ from those in the pathogen-induced SAR pathway. ISR is mainly regulated by the jasmonic acid (JA) and ethylene (ET) signaling routes (Glazebrook 2005; Van Baarlen et al. 2007). JA induces the expression of genes encoding defense-related proteins, such as thionins (Epple et al. 1995) and proteinase inhibitors (Farmer et al. 1992), whereas ET activates several members of the pathogenesis-related (PR) gene superfamily (Potter et al. 1993). Both regulators are involved in the activation of genes encoding plant defensins (Penninckx et al. 1996) and enzymes for phytoalexin biosynthesis (Gundlach et al. 1992). SAR is characterized by an early increase in salicylic acid (SA) (Malamy et al. 1990) and the concomitant activation of $P R-1$ gene expression (Ward et al. 1991) whereas plants expressing ISR did not, confirming that ISR and SAR are controlled by distinct signaling pathways that diverge in their requirement for SA. PR-1 has been extensively used as a marker for SA-mediated SAR defense, whereas the expression level of PDF1.2 and PDF2.3 is not influenced by SA.

Here, we demonstrate that expression of $B v G L P-1$ in transgenic Arabidopsis increases the $\mathrm{H}_{2} \mathrm{O}_{2}$ content in transgenic Arabidopsis plants and confers resistance to two fungal pathogens, $R$. solani and $V$. longisporum, but does not affect the beneficial interaction induced by $P$. indica in transgenic Arabidopsis seedlings even though the antifungal activity of $B v G L P$ 1 seems to restrict growth of $P$. indica in older plants. Furthermore, $B v G L P-1$ specifically activates expression of a subset of defense-related proteins in Arabidopsis. These data suggest that $B v G L P-1$ establishes plant resistance following a signaling route diverging from that induced by $P$. indica.

\section{RESULTS}

\section{Generation and selection}

of transgenic Arabidopsis plants expressing BvGLP-1.

Twenty-two independent transgenic plants transformed with pAM194-BvGLP-1 were generated. From these, six plants which carry a single copy of the transgene were chosen for generation of homozygous transgenic lines by a successive propagation (data not shown). The transcriptional activity of the transgene in six homozygous transgenic lines was determined by reverse-transcriptase polymerase chain reaction (RT-PCR) assay with $B v G L P$-1-specific primers. An RT-PCR fragment of $780 \mathrm{bp}$ in size, as expected, was given in all six transgenic lines but not in the wild-type control (Fig. 1A), suggesting that $B v G L P-1$ is transcriptionally active in transgenic plants. Because BvGLP-1 may function as an enzyme with OxO or SOD producing $\mathrm{H}_{2} \mathrm{O}_{2}$ in plant cells, we expected for an elevated $\mathrm{H}_{2} \mathrm{O}_{2}$ level in transgenic plants expressing $B v G L P-1$. To confirm this, we colorimetrically determined the $\mathrm{H}_{2} \mathrm{O}_{2}$ content in transgenic Arabidopsis plants in comparison with that in wildtype $\mathrm{C} 24$ plants. A slight variability in $\mathrm{H}_{2} \mathrm{O}_{2}$ levels was observed in different transgenic lines but the levels are all significantly higher than those in the wild-type $\mathrm{C} 24$ control plants (Fig. 1B). Thus, the elevation of $\mathrm{H}_{2} \mathrm{O}_{2}$ content in transgenic plants expressing $B v G L P-1$ suggests the OxO or SOD activity of BvGLP-1. Transgenic lines 1, 2, and 3 were chosen for further experiments in this study because of their relatively higher $\mathrm{H}_{2} \mathrm{O}_{2}$ content (Fig. 1B). Visually, no obvious differences in growth rate and morphology between transgenic and wild-type Arabidopsis plants were observed (data not shown).

\section{Infection experiments of Arabidopsis plants with $\boldsymbol{R}$. solani and $P$. indica on agar plates.}

To check the role of BvGLP-1 in pathogenic and beneficial plant-fungus interactions, we infected the transgenic Arabidopsis plants with $R$. solani (AG 2-1) and $P$. indica on agar plates in which the wild-type $\mathrm{C} 24$ plants served as a control. For infection with $R$. solani, wild-type and transgenic plants were transferred to agar plates, inoculated with fungal mycelium, and cocultivated in a growth chamber. Three days after infection, wild-type $\mathrm{C} 24$ plants showed clear disease symptoms, and $23 \pm 3 \%(n=30)$ of them suffered from the infection (Fig. 2), whereas only a few transgenic plants $(4 \pm 1 \%)$ showed visible symptoms. Twelve days after infection, wildtype plants suffered seriously from the fungal infection; they showed strong disease symptoms and $97 \pm 3 \%(n=30)$ of the infected plants died (Fig. 3B). In contrast, more than $50 \pm 3 \%$ $(n=30)$ of the transgenic plants were still healthy and grew regularly. These data demonstrated that the expression of 
$B v G L P-1$ in Arabidopsis interferes with $R$. solani infection, giving rise to significant resistance against the pathogen.

A similar experiment was performed with $P$. indica. Wildtype and transgenic plants were transferred to agar plates with fungal plaque (Fig. 4A). After 10 days of cocultivation, we observed a $24 \pm 4 \%$ ( $n=60$ plates $)$ increase in the fresh weight of wild-type seedlings cocultivated with $P$. indica relative to the uncolonized control. A similar result was obtained for the three transgenic Arabidopsis lines (Fig. 4B). We conclude that processes leading to $P$. indica-mediated growth promotion of Arabidopsis seedlings on agar plates are independent of BvGLP-1 expression and that higher $\mathrm{H}_{2} \mathrm{O}_{2}$ levels do not prevent the beneficial effects for the seedlings.

\section{Infection experiments of Arabidopsis plants} with $R$. solani and $V$. longisporum in soil.

To verify the data obtained from the agar plate experiments, we assessed the resistance of the $B v G L P$-1-expressing Arabi-

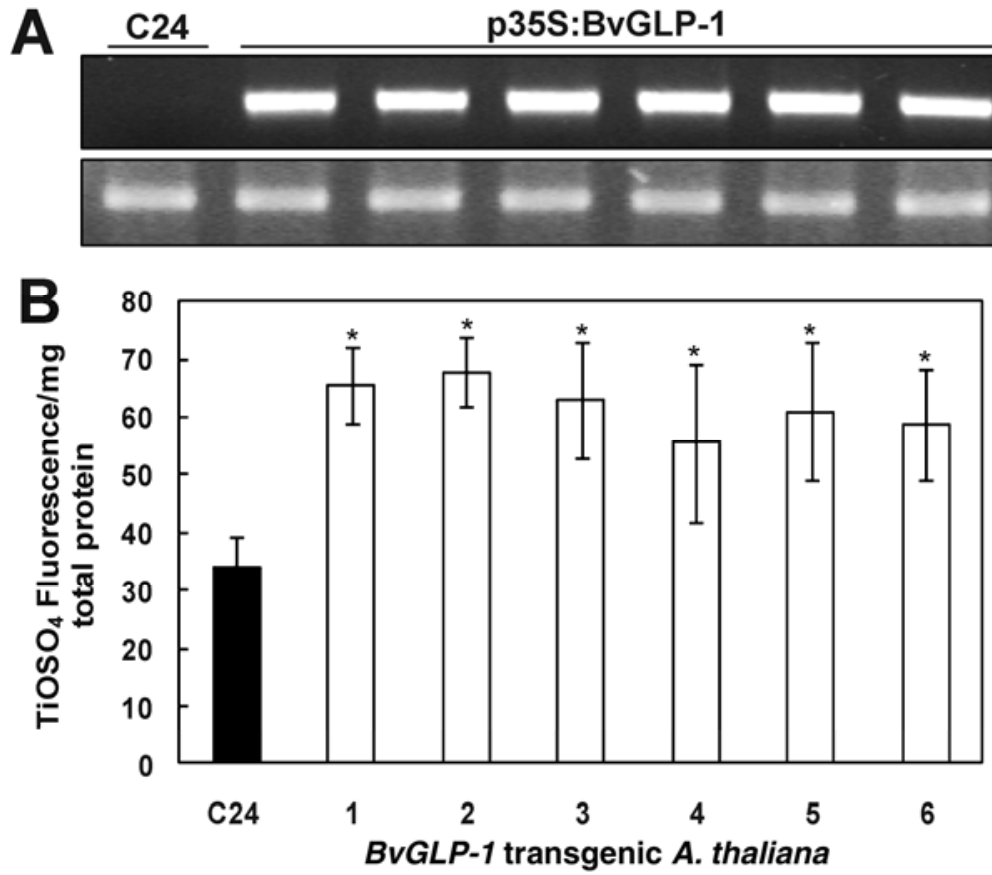

Fig. 1. Characterization of transgenic Arabidopsis thaliana lines transformed with pAM194-BvGLP-1. A, Reverse-transcriptase polymerase chain reaction analysis with six homozygous transgenic A. thaliana lines (BvGLP-1) using BvGLP-1-specific primers. Arabidopsis wild-type plants (C24) served as control. The $B v G L P-1$ transcript of expected size is present in all transgenic lines but not in the control. The messenger (m)RNA levels for each cDNA probe were normalized with the ubiquitin mRNA level. B, Determination of the content of hydrogen peroxide $\left(\mathrm{H}_{2} \mathrm{O}_{2}\right)$ in 7 -day-old $B v G L P-1$ transgenic $A$. thaliana (white) and the wild-type $\mathrm{C} 24$ (black). The $\mathrm{H}_{2} \mathrm{O}_{2}$ level was measured colorimetrically as described by Jana and Choudhuri (1982). Bars represent standard errors based on three independent experiments with 10 plants each. The assays show significant difference in $\mathrm{H}_{2} \mathrm{O}_{2}$ levels between transgenic lines and the wild-type Arabidopsis control as indicated by an asterisk. Significance tests were performed with Student's $t$ test $(P<0.05)$.

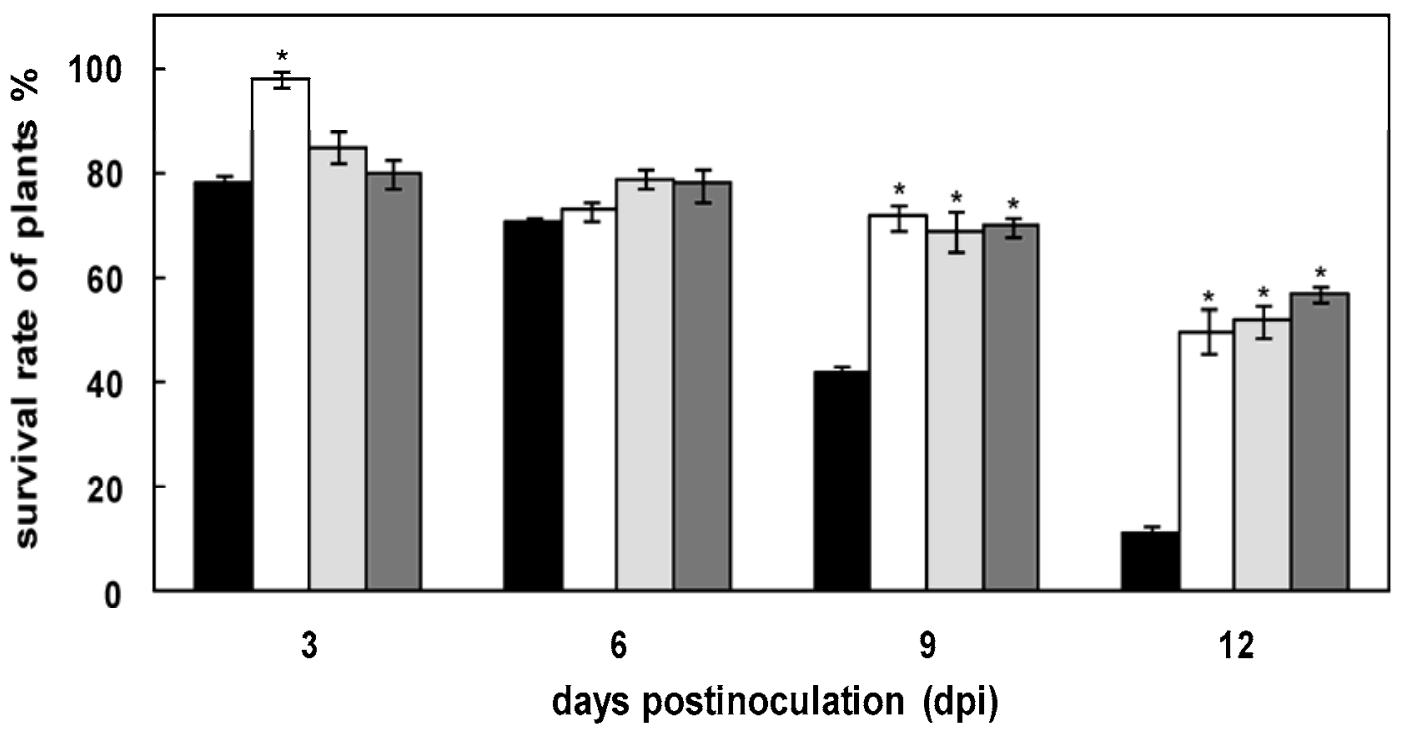

Fig. 2. Survival rate of Arabidopsis plants after Rhizoctonia solani infection in agar test. Plants of three independent BvGLP-1 transgenic Arabidopsis thaliana lines (white, light gray, and gray bars) and wild-type C24 (black) were infected with $R$. solani AG2-1. Seven-day-old seedlings of $A$. thaliana were transferred to agar plates for infection and the plant survival rate was scored 3, 6, 9, and 12 days postinoculation. Bars represent standard errors based on three independent experiments with 10 plants each. The data show significant differences in plant survival rates between transgenic lines and the wild-type control 9 and 12 days postinoculation. The asterisk indicates significance compared with the control (black bars) in each group according to the Student's $t$ test $(P<0.05)$. 
dopsis plants against $R$. solani in soil. For the $R$. solani infection assay, wild-type and transgenic Arabidopsis plants were directly transferred to pots filled with $R$. solani-infected soil and cocultivated in a growth chamber in which noninfected plants served as a control. No obvious growth and morphological differences between noninfected transgenic and wild-type Arabidopsis plants were visible (Fig. 3A). Seven days after cocultivation, clear differences between wild-type and transgenic plants were obvious (Fig. 5): strong symptoms appeared on most leaf surfaces of wild-type plants and more than $40 \% \pm$ $3 \%$ of them died after $R$. solani infection. In contrast, transgenic plants grew regularly even though slight disease symptoms were visible on a few leaves (Figs. 3A and 5). Twentyone days after cocultivation, $87 \pm 3 \%$ of the wild-type plants died after fungal infection while more than $76 \pm 3 \%$ of transgenic plants survived (Fig. 5). These data are consistent with the results obtained from the agar plate assays and demonstrate that the expression of $B v G L P-1$ in Arabidopsis confers significant resistance against $R$. solani infection.
A similar experiment was performed with $V$. longisporum. Wild-type and transgenic Arabidopsis seedlings were grown in small pots filled with soil for 14 days before infection. The infected plants were scored weekly and classified into the categories 1 to 9 , based on the development of the disease symptoms (Table 1). Clear differences in the development of the disease symptoms were observed between transgenic and wild-type plants (Table 1; Fig. 3A). Fourteen days after infection, the first disease symptoms appeared on wild-type plants, in the form of chlorosis and dark-colored veins, mainly on older leaves but not yet on transgenic leaves, on which the first slight disease symptoms were only visible 21 days after infection (Table 1; Fig. 3A). After 21 days, noninoculated plants showed slight visual symptoms of senescence (score 1 to 2 ), wild-type plants suffered heavily from fungal infection, and more than $50 \%$ of the leaves showed severe disease symptoms (score 4 to 5) (Table 1). At 28 days after infection, more than $50 \%$ of the leaves of wild-type plants were dead (score 5 to 7 ), whereas only slight disease symptoms were detectable on the
A
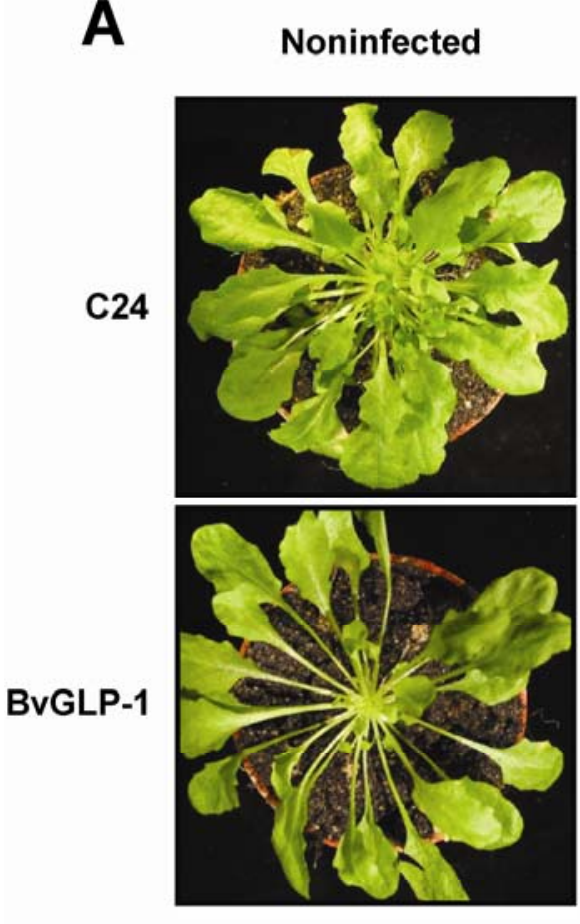

BvGLP-1

C24

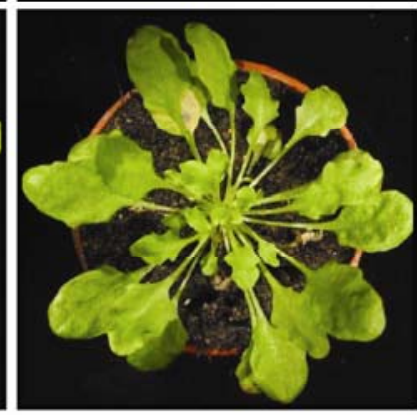

Rhizoctonia solani
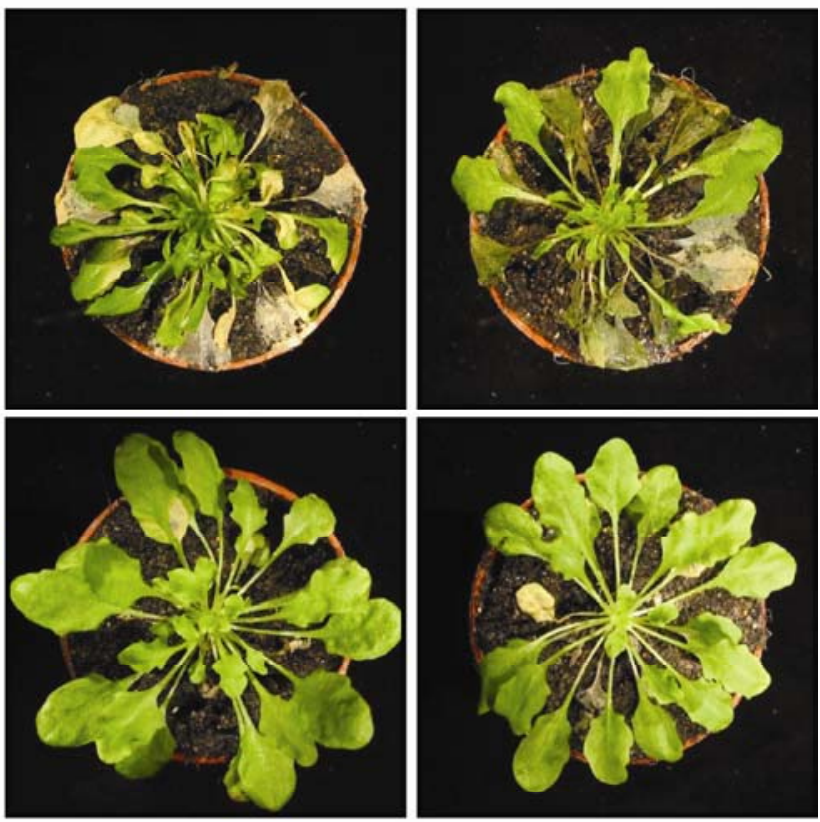

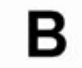

BvGLP-1

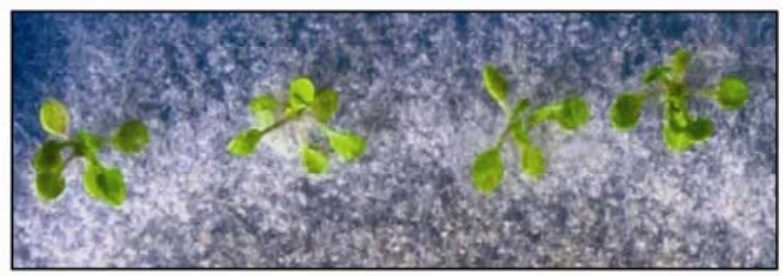

C24

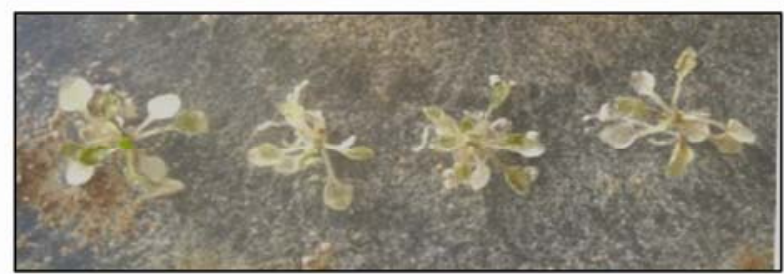

Fig. 3. Examples of visual comparison between infected transgenic Arabidopsis thaliana expressing BvGLP-1 and wild-type C24 plants in soil as well as on agar plates. A, Arabidopsis wild-type C24 and BvGLP-1-transgenic Arabidopsis plants infected with Verticillium longisporum and Rhizoctonia solani in soil 21 days postinoculation. Noninfected plants served as control. B, Arabidopsis wild-type C24 and BvGLP-1-transgenic Arabidopsis plants infected with $R$. solani on agar plate 12 days postinoculation. 


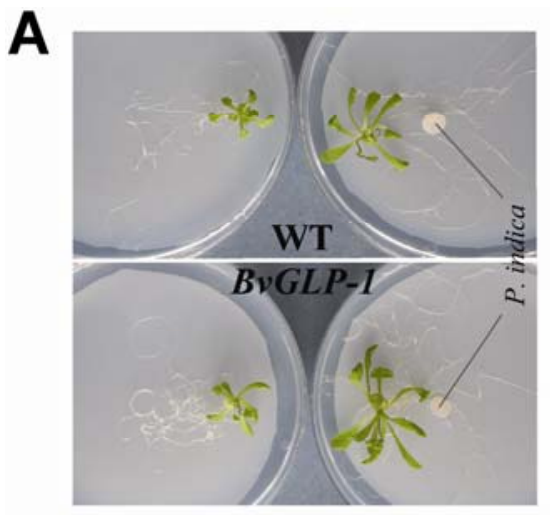

B
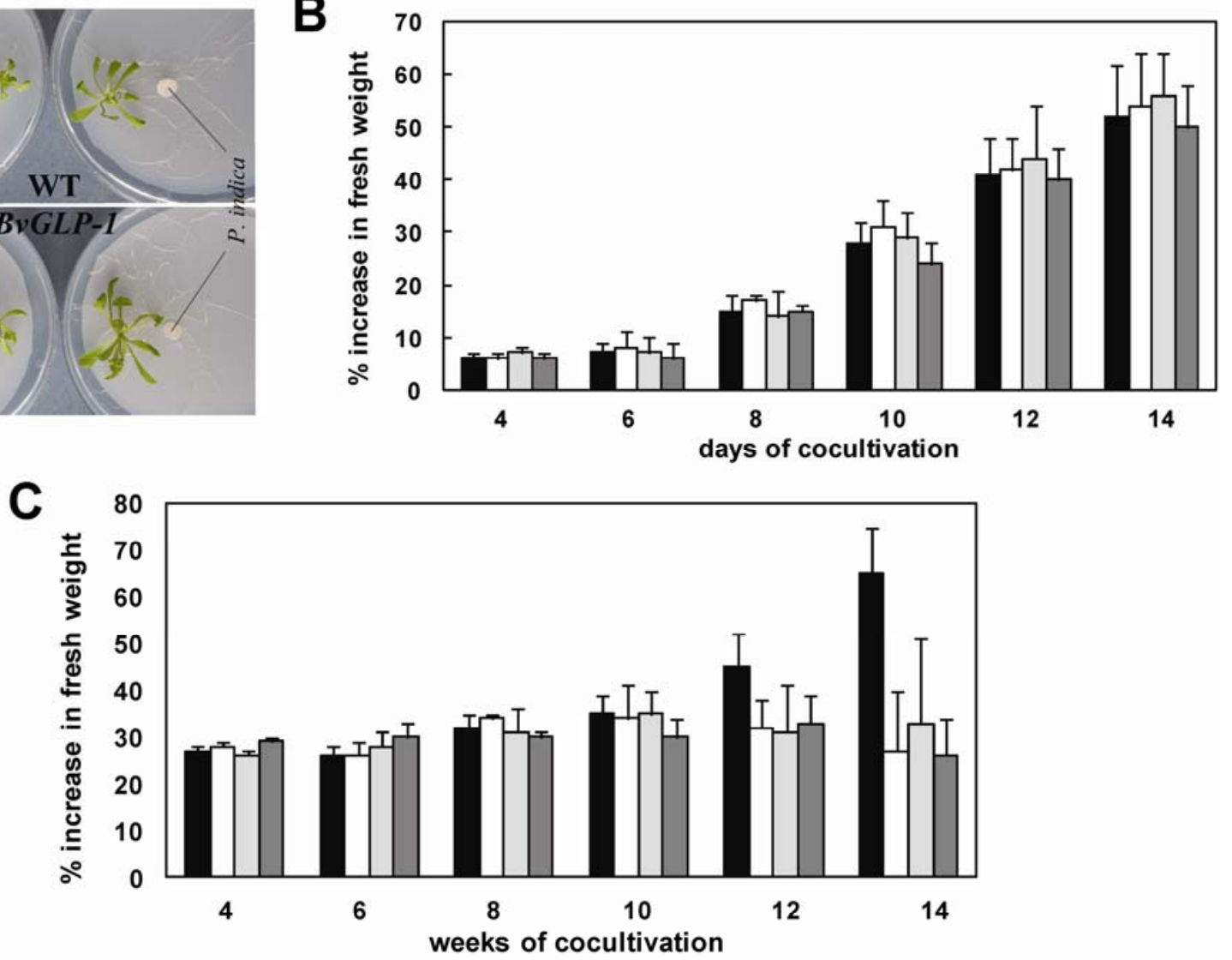

D $\quad$ WT

BVGLP-1

\begin{tabular}{|c|c|c|c|c|c|c|c|c|c|c|c|c|}
\hline & \multicolumn{3}{|c|}{ - P. indica } & \multicolumn{3}{|c|}{$+P$. indica } & \multicolumn{3}{|c|}{ - P. indica } & \multicolumn{3}{|c|}{$+P$. indica } \\
\hline & 8 & 10 & 14 & 8 & 10 & 14 & 8 & 10 & 14 & 8 & 10 & 4 \\
\hline Pitef1 & & & & & & $\sigma$ & & & & & & \\
\hline
\end{tabular}

\begin{tabular}{l|c|c|c|c|c|c|} 
E & \multicolumn{3}{|c|}{$\begin{array}{c}\text { WT } \\
\text { weeks postinoculation } \\
\text { with } P \text {. indica }\end{array}$} & \multicolumn{3}{|c|}{$\begin{array}{c}\text { BvGLP1 } \\
\text { weeks postinoculation } \\
\text { with } P \text {. indica }\end{array}$} \\
Ratio & 8 & 10 & 14 & 8 & 10 & 14 \\
\hline cPitef1/actin & $1.0 \pm 0.2$ & $0.9 \pm 0.2$ & $1.2 \pm 0.1$ & $1.1 \pm 0.2$ & $0.7 \pm 0.2$ & $0.4 \pm 0.2$ \\
\hline gPtief1/actin & $1.0 \pm 0.1$ & $1.0 \pm 0.2$ & $1.1 \pm 0.1$ & $1.0 \pm 0.2$ & $0.8 \pm 0.1$ & $0.5 \pm 0.2$
\end{tabular}

Fig. 4. A, Cocultivation of wild-type (WT) and transgenic Arabidopsis seedlings with Piriformospora indica for 10 days. Arabidopsis thaliana seedlings were transferred to nylon discs placed on top of a modified PNM culture medium (Peškan-Berghöfer et al. 2004). One seedling was used per petri dish. B, Increase in fresh weight (\%) of WT seedlings (black bars) and seedlings of $B v G L P-1$ transgenic lines (white, light gray, and gray bars) cocultivated with $P$. indica for 4 to 14 days compared with the uncolonized control. Bars represent standard errors based on three independent experiments with 60 seedlings each. The increase in fresh weight of WT seedlings (black) and seedlings of $3 B v G L P-1$ transgenic lines (white, light gray and gray bars) was significant between different time points ( 4 to 14 days) based on ANOVA analysis $(P<0.05)$. C, Increase in fresh weight $(\%)$ of WT (black) and $B v G L P-1$ transgenic lines (white, light gray, and gray bars) cocultivated with $P$. indica for 4 to 14 weeks compared with the uncolonized control. Bars represent standard errors based on three independent experiments with 60 plants each. No significant differences in fresh weight of seedlings of $B v G L P-1$ transgenic lines (white, light gray, and gray bars) were found between different time points ( 4 to 14 weeks) based on analysis of variance $(P<0.05)$. D, Colonization assays of the roots of 8 - to 14-week-old WT and BvGLP-1-transgenic Arabidopsis plants grown in the presence (+) of $P$. indica; absence (-) served as control. The transcript levels of the fungal translation elongation factor 1 messenger $(\mathrm{m}) \mathrm{RNA}(\mathrm{cPitef1})$ in the roots of colonized Arabidopsis seedlings were compared with the amount of the plant actin mRNA levels based on semiquantitative real-time polymerase chain reaction. RNA was isolated from the roots of the transgenic lines and the WT. After reverse transcription, cPitefl and actin were amplified. A significant reduction in the amount of fungal RNA was detected in the 14-week-old transgenic plants compared with the WT. E, Determination of the root colonization degree of WT and transgenic Arabidopsis plants. The transcript level of the fungal translation elongation factor 1 mRNA (cPitefl) and genomic DNA (gPitefl) in the roots of colonized Arabidopsis seedlings was compared with the amount of the plant actin nucleic acids resulting in the cPitefl/actin mRNA and gPitefl/actin mRNA ratios. The ratio of WT plants cocultivated with P. indica for 8 weeks was taken as 1.0 and the other values are expressed relative to it. A significant difference in the degree of root colonization was observed between WT and transgenic plants 14 weeks after cocultivation. Significance tests were performed with Student's $t$ test $(P<0.05)$. 
oldest leaves of the transgenic plants (score 1 to 2 ). These data suggest that the expression of BvGLP-1 in Arabidopsis reduces the susceptibility of the plants to $V$. longisporum infection.

\section{Microscopic observations of Arabidopsis roots infected with the phytopathogenic fungi.}

For microscopic observation of the $R$. solani infection process, we stained the infected roots with lactophenol blue solution 3 and 7 days postinoculation. The lactophenol blue stained fungal hyphae. Washing the root system with the running tap water removed most of the nonattached mycelium. A dramatic reduction in the amount of fungal hyphae on the root surface (Fig. 6A and B) as well as of fungal mycelium normally developed inside the roots (data not shown) was observed in transgenic Arabidopsis when compared with wild-type roots. This result implies that the penetration as well as the development of the fungus in transgenic Arabidopsis roots was strongly inhibited. Accordingly, apart from the lower number of infections, the size of the lesions on the transgenic leaves was also reduced when compared with the wild-type plants (Fig. 6C and D). In conclusion, the microscopic observations support the finding from the infection experiments that BvGLP-1 inhibits fungal infections on transgenic Arabidopsis plants.

\section{Analysis of the transcript levels}

of selected defense related genes in transgenic plants.

PR proteins are involved in plant resistance to fungal infection. To define whether the resistance observed in this study is correlated with defense gene expression, we analyzed the $P R$ and $P D F$ transcript levels in noninoculated transgenic Arabidopsis plants and compared them with those in noninoculated wild-type plants by real-time PCR. All transgenic plants exhibited elevated levels of $B v G L P-1$ transcripts (Fig. 1A). Even without pathogen attack, a strong transcriptional upregulation of $P R-1$ to $P R-4$ genes was observed in all selected transgenic lines compared with the wild-type control (Fig. 7) whereas no significant change in transcript level for PDF 2.3 was visible. Furthermore, although the expression of PDF1.2 was significantly upregulated in transgenic plants, the expression PDF2.1 was downregulated when compared with the wild type (Fig. 7). Thus, BvGLP-1 appears to regulate the expression of a subset of plant defense-related genes, leading to enhanced tolerance or resistance.

\section{Cocultivation of Arabidopsis} with the growth-promoting fungus $P$. indica in soil.

To evaluate the long-term impact of the BvGLP-1 expression on a beneficial plant-fungus interaction, we performed a wholelife cocultivation assay of Arabidopsis with $P$. indica in soil. To this end, we transferred Arabidopsis plants cocultivated with or without the fungus from agar plates to pots. A growth promotion for the transgenic plants cocultivated with the fungus was still observed over a period of 4 to 8 weeks, and this promotion was comparable with the wild type (Fig. 4C). However, although the wild-type plants also responded to the fungus during later phases, flowered approximately 2 weeks earlier than the uncolonized control, and produced more seed, the beneficial effects for the transgenic plants became less (Fig. 4C). We observed only a slight but not significant increase in the fresh weight before the plants set flowers, the flowering time was only a few days earlier, and the seed yield was increased by only $5 \% \pm 2 \%$ compared with the uncolonized transgenic plants.

Table 1. Disease scores on Arabidopsis thaliana plants inoculated with Verticillium longisporum in soil ${ }^{\mathrm{a}}$

\begin{tabular}{lccccc}
\hline & & \multicolumn{5}{c}{$\begin{array}{c}\text { Disease scores at days } \\
\text { postinoculation }\end{array}$} \\
\cline { 3 - 6 } Line & No. of seedlings & $\mathbf{7}$ & $\mathbf{1 4}$ & $\mathbf{2 1}$ & $\mathbf{2 8}$ \\
\hline Noninfected C24 & 30 & 1 & 1 & 1 to 2 & 1 to 2 \\
Infected C24 & 30 & 1 & 2 & 4 to 5 & 5 to 7 \\
Noninfected BvGLP-1 & 30 & 1 & 1 & 1 to 2 & 1 to 2 \\
Infected BvGLP-1 & 30 & 1 & 1 & 1 to 2 & 2 \\
Noninfected BvGLP- & 30 & 1 & 1 & 1 & 1 to 2 \\
1-2 & 30 & 1 & 1 & 2 & 2 \\
Infected BvGLP-1-2 & 30 & 1 & 1 & 1 & 2 \\
Noninfected BvGLP- & & & & & 2 \\
1-3 & 30 & 1 & 1 & 1 & 2 \\
Infected BvGLP-1-3 & & & & & \\
\hline
\end{tabular}

${ }^{a}$ Plants of three independent $B v G L P-1$ transgenic A. thaliana lines and wild-type C24 were infected with $V$. longisporum. Assessment for scoring disease symptoms induced by the Verticillium sp. was performed according to Zeise (1992): 1, no symptoms; 2, slight symptoms on oldest leaf (yellowing, black veins); 3 , slight symptoms on next younger leaves; 4 , approximately $50 \%$ of leaves show symptoms; $5,>50 \%$ of leaves show symptoms; 6 , up to $50 \%$ of leaves are dead; $7,>50 \%$ of leaves are dead; 8 , only the apical meristem is still alive; 9, plants are dead. Disease scores were based on three independent experiments with 10 plants each. Noninfected plants served as control.

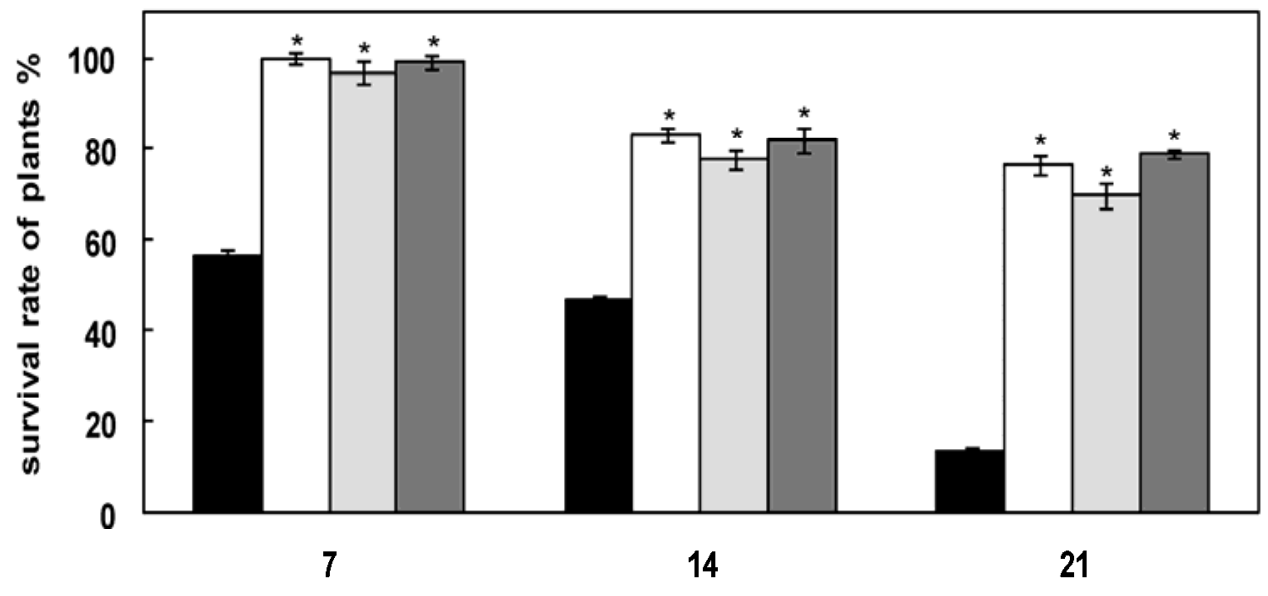

days postinoculation (dpi)

Fig. 5. Survival rate of Arabidopsis plants infected with Rhizoctonia solani AG2-1 in soil. Plants of three independent BvGLP-1 transgenic Arabidopsis thaliana lines (white, light gray, and gray bars) and wild-type C24 (black) were infected with $R$. solani AG2-1. Seven-day-old seedlings of $A$. thaliana were transferred to soil for infection and the plant survival rate was scored 7, 14, and 21 days postinoculation. Bars represent standard errors based on three independent experiments with 10 plants each. The data show significant differences in plant survival rates between transgenic lines and the wild-type control 7 , 14, and 21 days after inoculation based on Student's $t$ test $(P<0.05)$, as indicated by an asterisk for each group. 
BvGLP-1
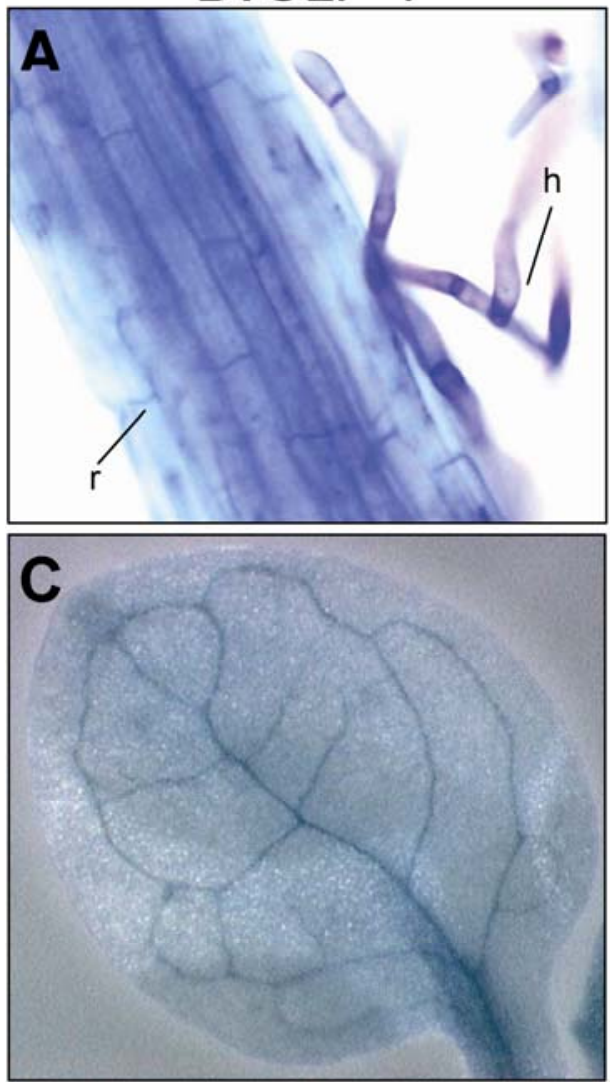

$\mathrm{C} 24$
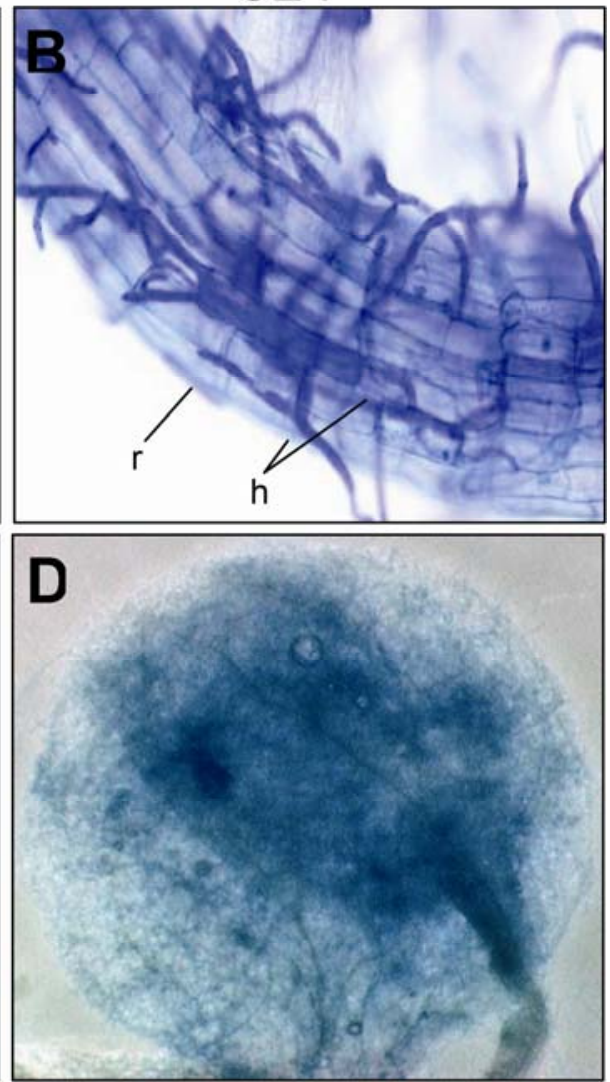

Fig. 6. Light microscopic observation of BvGLP-1 transgenic and wild-type Arabidopsis plants infected with Rhizoctonia solani after washing and staining with lactophenol blue solution 3 days (roots) and 7 days (leaves) postinoculation, respectively. A, $R$. solani growing in an undirected manner on the root surface of BvGLP-1 transgenic Arabidopsis without firm attachment and B, attachment and directed-growth of $R$. solani hyphae over the root of Arabidopsis wild-type plants and formation of dome-like infection cushions. C, Intact leaf of BvGLP-1 transgenic Arabidopsis and D, overgrowing of $R$. solani in Arabidopsis wild-type plants leading to leaf and tissue maceration. Symbols: $\mathrm{r}=\mathrm{root}, \mathrm{m}=$ mycelium, $\mathrm{h}=\mathrm{hyphae}$.

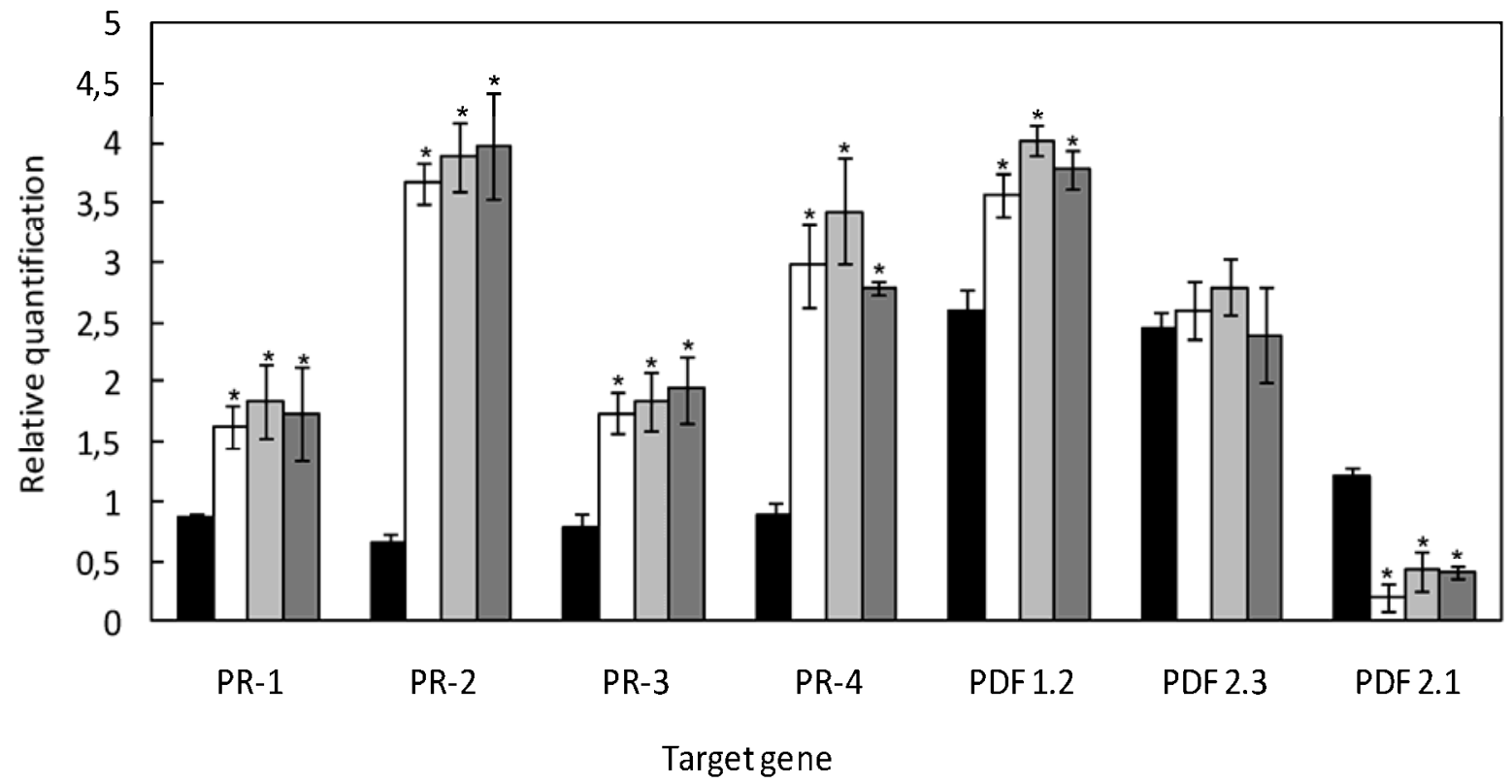

Fig. 7. Transcript analysis of $B v G L P-1$-activated defense related genes in transgenic Arabidopsis plants. Each pathogenesis-related ( $P R)$ and $P D F$ gene expression level was determined by real-time polymerase chain reaction with three independent BvGLP-1-transgenic Arabidopsis lines. Wild-type Arabidopsis C24 plants served as control. Transcript levels for each gene were normalized with the ubiquitin messenger RNA level. Bars represent standard errors based on three independent experiments with 10 plants each. Transcript levels of PR-1, PR-2, PR-3, PR-4, and PDF1.2 but not of PDF2.3 were significantly higher in transgenic lines than in the wild-type control. In contrast, transcription of PDF2.1 in transgenic lines was significantly suppressed. Significance determined with the Student's $t$ test $(P<0.05)$ was indicated by an asterisk in each group. 
Because root colonization is a critical parameter for the beneficial interaction between $P$. indica and Arabidopsis, we checked the degree of root colonization of the transgenic plants and compared it with the wild type. We extracted RNA or DNA from the roots of 8- to 14-week-old plants cocultivated with $P$. indica for determination of root colonization by real-time PCR analysis. In both cases, the ratios were not significantly different (Fig. 4E), indicating that the Pitefl messenger (m)RNA level is proportional to the amount of the Pitefl DNA during our experimental conditions. No significant difference in the degree of root colonization was detected for wild-type and transgenic plants cocultivated with the fungus for 8 weeks (Fig. 4D and E) but we observed a significant reduction in the amount of fungal DNA or RNA in the 14-week-old transgenic plants when compared with the wild type (Fig. 4D and E). In two independent experiments with 30 plants each, root colonization was reduced by approximately $65 \%$ compared with the wild type. These results indicate that BvGLP-1 expression restricts root colonization during later growth phases, which subsequently leads to a decrease in benefits to the plant.

\section{DISCUSSION}

Plant GLP genes are members of large multigene families exhibiting diverse patterns of expression (Bernier and Berna 2001). Transgenic approaches make use of ectopic expression of GLP gene-enhanced resistance or tolerance to various pathogenic organisms, including Sclerotinia sclerotiorum, Septoria musiva, Ostrinia nubilalis, and Blumeria graminis (Thompson et al. 1995; Schweizer et al. 1999; Donaldson et al. 2001; Liang et al. 2001; Ramputh et al. 2002; Christensen et al. 2004). We extended these studies by using soilborne fungal pathogens and demonstrated that BvGLP-1 confers broad resistance to the two phytopathogenic fungi $R$. solani and $V$. longisporum when transferred into Arabidopsis. We found that BvGLP-1 expression in Arabidopsis stimulates the $\mathrm{H}_{2} \mathrm{O}_{2}$ production in plant cells, thus strongly suggesting its $\mathrm{OxO}$ or SOD activity, even though its enzymatic activity still remains to be determined. In sugar beet, the expression of $B v G L P-1$ is induced by nematode infection in resistant plants; therefore, it is reasonable to speculate that BvGLP-1 may represent a key point regulating plant defense responses, although the mechanism by which BvGLP-1 confers resistance to these pathogens is unclear thus far.

A possible explanation for the antifungal function of BvGLP-1 in Arabidopsis could be the generation of $\mathrm{H}_{2} \mathrm{O}_{2}$ through its enzymatic activity (OxO or SOD) in plant cells. $\mathrm{H}_{2} \mathrm{O}_{2}$ is important for reinforcement of the cell wall by crosslinking of plant cell wall proteins in papillae at the infection sites. Consequently, this leads to the protection of the cell against fungal penetration. In support of this, in our microscopic observations we found a drastic reduction in the amount of attached $R$. solani hyphae on the root surface as well as of developed hyphae within root cells in transgenic plants compared with the wild type, suggesting a strongly reduced penetration and development of the fungus in transgenic Arabidopsis roots. Local accumulation of $\mathrm{H}_{2} \mathrm{O}_{2}$ has been found in several barley-B. graminis interactions to be correlated with mlomediated resistance (Piffanelli et al. 2002). Furthermore, an enhanced resistance by transient overexpression of HvGER5a in epidermal barley cells was found to be dependent on its SOD activity (Zimmermann et al. 2006). Similar observations have been also reported by Olson and Varner (1993), ThordalChristensen and associates (1997), Wei and associates (1998), and Christensen and associates (2004).

On the other hand, $\mathrm{H}_{2} \mathrm{O}_{2}$ produced by BvGLP-1 may function as a signal molecule activating plant defense responses. Sig- naling pathways required for plant defense responses are complex, and even members from the same gene family that are induced by a single pathogen may require different signal molecules or combinations of signaling pathways for their expression (Ferrari et al. 2003). SA, JA, and ET are hormones involved in the regulation of resistance against different pathogens. SA is a key regulator of pathogen-induced SAR (Gaffney et al. 1993), whereas JA and ET regulate a largely distinct set of genes and are required for ISR. Both types of induced resistance are effective against a broad spectrum of pathogens, and several lines of evidence demonstrate cross talk between the pathways (Glazebrook 2005). It appears that defense genes that are activated against necrotrophic fungi are regulated primarily by the ET and JA signal transduction pathways, whereas biotrophic pathogens are countered more efficiently by SA-controlled defense mechanisms (Thomma et al. 1998). To test whether Arabidopsis plants overexpressing BvGLP-1 induce defense genes from SAR or other defense pathways, we analyzed the expression of $P R$ and $P D F$ genes, representative for two different signaling pathways (Thomma et al. 1998). In Arabidopsis, induction of $P R-1, P R-2$, and $P R-5$ follows an SA-dependent pathway, whereas the induction of the plant defensin PDF1.2, the basic chitinase gene $P R-3$, and the hevein-like protein gene $P R-4$ depends on a pathway involving at least JA as a signal molecule (Li et al. 2004). When $B v G L P$ 1 was overexpressed in Arabidopsis, transgenic plants exhibited enhanced transcript levels for PR1-4 and PDF1.2. Hence, $B v G L P-1$ expression in Arabidopsis leads to the activation of both the SA- und JA/ET-dependent pathways, because the SAdependent $P R-1$ and $P R-2$ genes and the JA/ET-dependent $P R$ 3 , $P R-4$, and $P D F 1.2$ genes are upregulated in the transgenic lines. Because activation of the respective genes in the transgenic lines occurs even in the absence of the pathogens, the plants appear to be better protected. This strongly suggests that BvGLP-1 may be functional as a key signaling component of plant resistance mechanisms by specifically regulating the expression of a set of plant defense-related genes prior to pathogen attack. In this context, transgenic sugar beet overexpressing $B v G L P-1$ will provide the final evidence of the gene function.

Oxalic acid (OA) represents an important virulence factor and acts as an elicitor inducing programmed cell death that is required for pathogenicity as well as for disease development of various fungal pathogens (Bateman and Beer 1965; Stone and Armentrout 1985; Godoy et al. 1990). It is reasonable to speculate that degradation of fungal OA may represent a possible mechanism of the $B v G L P-1$-mediated resistance against the two fungal pathogens studied here, $V$. longisporum and $R$. solani. Evidently, overexpression of an oxalate decarboxylase from Collybia velutipes, an OA-degrading enzyme, was found to confer resistance to infection caused by the OA-producing fungus Sclerotinia sclerotiorum in transgenic tobacco and tomato (Kesarwani et al. 2000). Similarly, soybean, tobacco, sunflower, and rapeseed plants transformed with a wheat $\mathrm{OxO}$ showed enhanced resistance to $S$. sclerotiorum (Zaghmout et al. 1997; Donaldson et al. 2001; Hu et al. 2003; Dong et al. 2008). In this scenario, an enhanced OxO activity leads to OA degradation (and, thus, an inhibition of toxin-induced cell death) on the one hand and $\mathrm{H}_{2} \mathrm{O}_{2}$ production (and, thus, a stimulation of the hypersensitive response) on the other hand. Further analyses are required to understand the enzymatic reaction of BvGLP-1 which leads to enhanced tolerance or resistance against $R$. solani and $V$. longisporum.

Interestingly, the presence of BvGLP-1 does not primarily affect the beneficial interaction between $P$. indica and Arabidopsis (Fig. 4). This clearly indicates that different signaling processes are required for the activation of the resistance against the two tested necrotrophs and the beneficial interaction with 
$P$. indica. However, in long-term cocultivation experiments (i.e., in older plants which were exposed to $P$. indica during their whole life), the expression of $B v G L P-1$ in plants appears to have an impact on growth and development of the beneficial fungus as well, because root colonization by $P$. indica is significantly reduced. We propose that, in older plants, BvGLP-1induced defense gene activation and $\mathrm{H}_{2} \mathrm{O}_{2}$ production restricts fungal growth and, thus, diminishes root colonization and the benefits for the plants. It has been proposed for barley that programmed cell death is required for the colonization of the roots by $P$. indica (Deshmukh et al. 2006); however, we do not have any evidence that this plays a role in this scenario. It is worth noting that, in spite of the reduced growth promotion during later stages of the interaction, we did not observe any harm to the plants, and the biomass and seed production was not lower for plants cocultivated with $P$. indica when compared with the uncolonized control.

Our results showed that the transgenic plants were not completely protected against infection by $R$. solani and $V$. longisporum, because they became infected and necrotic after a longer period of infection. It has been reported that overexpression of PR proteins such as chitinases (Broglie et al. 1991, Datta et al. 2000) or a ribosome-inactivating protein (Maddaloni et al. 1997) resulted in enhanced resistance to R. solani, primarily through a delay in the development of disease symptoms. However, the observed delay of the disease may give the transgenic plants enough time to induce defense mechanisms to ward off the pathogen systemically. Because of a broad resistance to various pathogens, $B v G L P-1$ provides a promising candidate gene for genetic engineering for improving crop resistance to different pathogens.

\section{MATERIALS AND METHODS}

\section{Plant material and fungal strains.}

Arabidopsis thaliana C24 (Lehle Seeds, Round Rock, TX, U.S.A.) was used for generation of transgenic plants. $R$. solani AG2-1 was grown on potato dextrose agar (PDA) for 7 days at $24^{\circ} \mathrm{C}$ with a 12 -h photoperiod according to Keijer and associates (1997). V. longisporum isolate 43, provided by E. Diederichsen (Institut für Biologie, Angewandte Genetik, FU Berlin), was cultured on PDA for 14 days in the dark and further cultivated every 2 to 3 weeks according to Eynck and associates (2007).

\section{Generation of transgenic A. thaliana plants.}

$B v G L P-1$ (GenBank accession number AY243465) was cloned into the binary vector pAM194 (KWS Saat AG, Einbeck, Germany) under the transcriptional control of the $35 \mathrm{~S}$ promoter, resulting in the plant expression construct pAM194-BvGLP-1. The recombinant binary vector was transformed into Agrobacterium tumefaciens GV3101 (Koncz and Schell 1986). Transgenic Arabidopsis plants were generated by using the root transformation protocol (Valvekens et al. 1988). Transgenic plants were propagated under selective condition to the T3 generation. The homozygous phenotype was selected by kanamycin resistance. The presence of the transgene was confirmed by transgene-specific PCR amplification.

\section{Infection assay of Arabidopsis plants with Rhizoctonia spp. on agar plates.}

Transgenic as well as wild-type Arabidopsis seed were sterilized with $5 \% \mathrm{Ca}(\mathrm{OCl})_{2}$ for $10 \mathrm{~min}$ and then in $70 \%$ ethanol for a further $5 \mathrm{~min}$. After washing with sterile water, seed were germinated on $0.2 \times$ KNOP medium (Knop 1860) for 5 days in a plant growth chamber $\left(22^{\circ} \mathrm{C}\right.$, photoperiod $=16 \mathrm{~h}$ of light and $8 \mathrm{~h}$ of darkness). Seedlings were transferred to new $0.2 \times$ KNOP agar plates for infection experiments in which the non- transgenic Arabidopsis seedlings served as a control. The seedlings were incubated with 1-cm-diameter mycelium plaques from 7-day-old potato dextrose $R$. solani culture. The plates were incubated in the growth chamber $\left(22^{\circ} \mathrm{C}\right.$, photoperiod $=$ $16 \mathrm{~h}$ of light and $8 \mathrm{~h}$ of darkness). At 3, 6, 9, and 12 days after inoculation, the plant survival ratio was scored.

\section{Infection assay of Arabidopsis plants with Rhizoctonia spp. in soil.}

Sterile soil was infected by placing a 1 -cm-diameter disc of mycelium isolated from 7-day-old potato dextrose broth culture of $R$. solani at a $1-\mathrm{cm}$ depth in each pot 10 days before planting. Arabidopsis seed were sterilized as described before and grown at $22^{\circ} \mathrm{C}$ with a photoperiod of $16 \mathrm{~h}$ of light and $8 \mathrm{~h}$ of darkness on agar plates containing $0.2 \times \mathrm{KNOP}$ medium for 7 days. One-week-old Arabidopsis seedlings were transferred to infected pots and grown in a growth chamber at $22^{\circ} \mathrm{C}$ with a photoperiod of $16 \mathrm{~h}$ of light and $8 \mathrm{~h}$ of darkness. Based on the symptoms, scored 7, 14, and 21 days after planting, plants were classified either to healthy (no or scarce disease symptoms) or diseased (severe wilting or dead plants) groups as described by Broglie and associates (1991) and Perl-Treves and associates (2004).

\section{Infection assay of Arabidopsis plants with Verticillium spp. in soil.}

Arabidopsis plants were cultivated in soil in small pots (diameter $=35 \mathrm{~mm}$ ) under short-day conditions (photoperiod = $16 \mathrm{~h}$ of light and $8 \mathrm{~h}$ of darkness). Spores of $\mathrm{V}$. longisporum were obtained by gently incubating in liquid CZAPEK-DOX medium for 14 days at $25^{\circ} \mathrm{C}$ on the rotary shaker. The resulting suspension was filtered through sterile gauze. Spore concentration was determined with a Fuchs-Rosenthal counting chamber. Infections were made by direct application of spore suspensions to the soil as described by Zeise and von Tiedemann (2002). Direct inoculation was conducted 2 weeks after germination. The pots were inoculated by infection of $1 \mathrm{ml}$ of conidia suspension $\left(4 \times 10^{7}\right.$ conidia $\left.\mathrm{ml}^{-1}\right)$ per plant near roots. Plants were scored weekly $(7,14,21$, and 28 days postinoculation) based on the developed disease symptoms and classified into nine classes (Zeise and von Tiedemann 2002) with the following modifications: 1 , no symptoms; 2 , slight symptoms on oldest leaf (yellowing, black veins); 3, slight symptoms on next younger leaves; 4 , approximately $50 \%$ of leaves show symptoms; $5,>50 \%$ of leaves show symptoms; 6 , up to $50 \%$ of leaves are dead; $7,>50 \%$ of leaves are dead; 8 , only the apical meristem is still alive; and 9, plants are dead.

\section{Cocultivation experiments with $\boldsymbol{P}$. indica.}

Arabidopsis seed were surface sterilized and placed on petri dishes containing Murashige and Skoog (MS) nutrient medium (Murashige and Skoog 1962). The plates were incubated for 7 days at $22^{\circ} \mathrm{C}$ under continuous illumination $\left(100 \mu \mathrm{mol} \mathrm{m} \mathrm{m}^{-2} \mathrm{~s}^{-}\right.$ $\left.{ }^{1}\right)$. $P$. indica was cultured as described previously (PeškanBerghöfer et al. 2004). After inoculation with the fungus, the plates were kept at room temperature in the dark for 1 to 2 weeks. Nine-day-old Arabidopsis thaliana seedlings were transferred to nylon discs (mesh size: $70 \mu \mathrm{m}$ ) placed on top of a modified PNM culture medium (Peškan-Berghöfer et al. 2004). One seedling was used per petri dish. After $24 \mathrm{~h}$, fungal plugs of $5 \mathrm{~mm}$ in diameter were placed at a distance of $1 \mathrm{~cm}$ from the roots. Plates were then incubated at $22^{\circ} \mathrm{C}$ under continuous illumination from the side. Plants were assayed 4, 6, 8, 10,12 , and 14 days after cocultivation. The experiments on soil were followed the protocol described by Peškan-Berghöfer and associates (2004). Arabidopsis seedlings were germinated on MS medium before transfer to sterile soil mixed with the 
Table 2. Primers used in the gene expression experiments

\begin{tabular}{lll}
\hline AGI number & Primer & \multicolumn{1}{c}{ Primer sequence 5'-3' $^{\prime}$} \\
\hline AT2G14610 & PR-1f/r & GGAGCTACGCAGAACAACTA/AGTATGGCTTCTCGTTCACA \\
AT3G57260 & PR-2 f/r & CTACAGAGATGGTGTCA/AGCTGAAGTAAGGGTAG \\
AT3G12500 & PR-3 f/r & TGGATGGGCTACAGCACC/CTAAATAGCAGCTTCGAGGAGG \\
AT3G04720 & PR-4 f/r & GGCCGGACAACAATGCGGTCGTCAAGG/CAAGCATGTTTCTGGAATCAGGCTGCC \\
AT5G44420 & PDF1.2 f/r & ATGGCTAAGTTTGCTTCCA/TTAACATGGGACGTAACAGATAC \\
AT2G02120 & PDF2.1 f/r & GATGGGTCCAGTCACGGTC/TTCAAGAACACACTAAACACGC \\
AT2G02130 & PDF2.3 f/r & CACACACAACTGTGCAAACG/CGGAAACACACAAACCAATG \\
AY243465 & BvGLP-1 f/r & CTCCTAGCCTCTTGTAATTCTAGC/GAATGGAAACAAGCAACATATGATATC \\
AT4G05320 & Ubiquitin & ACTCTCACCGGAAAGACAATC/TGACGTTGTCGATGGTGTCAG \\
At3G53750 & Actin & GGTCGTGACCTCACAGATGCTCGCTCCTGCTCATAGTCAAGAGC \\
\hline
\end{tabular}

fungus $(0.6 \%, \mathrm{wt} / \mathrm{wt})$. Cultivation occurred in multi-trays with Aracon tubes in a plant growth chamber at $22^{\circ} \mathrm{C}$ under longday conditions. For the exposure of Arabidopsis seedlings to a loan of $P$. indica, the fungus was inoculated in liquid KM media (Vadassery et al. 2009) until an optical density at $650 \mathrm{~nm}$ of 0.5 , and $3.5 \mathrm{ml}$ of this suspension was distributed on top of a petri dish containing $20 \mathrm{ml}$ of the modified PNM culture medium. The plates were then incubated at $22^{\circ} \mathrm{C}$ under continuous illumination $\left(80 \mu \mathrm{mol} \mathrm{m} \mathrm{m}^{-2} \mathrm{~s}^{-2}\right)$ for $72 \mathrm{~h}$. During this time, the fungal hyphae started to develop a loan. Then, 9-day-old Arabidopsis seedlings were transferred to the loan.

\section{Determination of the degree of root colonization.}

Roots of sterile seedlings or plants in pots cocultivated with $P$. indica were used for the determination of colonization. The colonized (and control) roots were removed from the soil, intensively rinsed with an excess of sterile water $(50 \mathrm{ml}$ each) to remove the soil and the loosely attached fungal hyphae, and then frozen in liquid nitrogen for RNA or DNA extraction. $P$. indica was monitored with a primer pair for the translation elongation factor 1 (Pitef1) (Bütehorn et al. 2000): ACCGTC TTGGGGTTGTATCC and TCGTCGCTGTCAACAAGATG. The degree of the root colonization was determined based on the ratios of Pitefl mRNA (cPtiefl) and Pitefl genomic DNA (gPtiefl) of the fungus relative to the actin RNA from the plant.

\section{Staining assays and light microscopy observations.}

Lactophenol blue staining was used to analyze host-pathogen interaction (Perl-Treves et al. 2004). To monitor fungal hyphae on or in Arabidopsis roots, seedlings were removed from agar plates and intensively washed with running tap water for 2 min to remove nonattached mycelium. The lactophenol blue staining was carried out in small petri dishes with gentle shaking, and seedlings were cleared using hot $10 \%$ (wt/vol) $\mathrm{KOH}$ for $10 \mathrm{~min}$. The seedlings were subsequently stained using lactophenol blue solution for $5 \mathrm{~min}$ and destained with water for at least $20 \mathrm{~min}$ until no more blue color came out. Stained seedlings were examined and documented under the bright-field microscope (Carl Zeiss MicroImaging GmbH, Göttingen, Germany).

\section{Semiquantitative- and real-time RT-PCR.}

Semiquantitative and real-time RT-PCR were used to assay the expression patterns of the genes of interest. Noninoculated transgenic as well as control Arabidopsis roots were removed from the soil or plates, rinsed 12 times with an excess of sterile water (50 ml each), and frozen in liquid nitrogen for RNA extraction. Extraction of total RNA from Arabidopsis roots was performed following the trizol protocol (Gibco BRL Life Technologies). The total RNA was treated with RNAse-free DNAse (Fermentas, St. Leon-Rot, Germany) for $60 \mathrm{~min}$ at $37^{\circ} \mathrm{C}$. Synthesis of cDNA was carried out using a Superscript III FirstStrand Synthesis System (Invitrogen, Karlsruhe, Germany) according to the instructions of the manufacturer. RT-PCR was performed in $50-\mu \mathrm{l}$ reactions consisting of $2.5 \mu \mathrm{l}$ of cDNA at 10 $\mathrm{ng} / \mu \mathrm{l}, 5 \mu \mathrm{l}$ of $10 \times$ buffer, $0.5 \mu \mathrm{l}$ of $10 \mathrm{mM}$ dNTPs, $5 \mu \mathrm{l}$ each of primer at $10 \mathrm{pmol} / \mu \mathrm{l}, 2.5$ units of Taq polymerase (Invitrogen), and $31.5 \mu \mathrm{H}_{2} \mathrm{O}$ under a PCR program of $94^{\circ} \mathrm{C}$ for $50 \mathrm{~s}, 54^{\circ} \mathrm{C}$ for $1 \mathrm{~min}$, and $72^{\circ} \mathrm{C}$ for $1 \mathrm{~min}$ for 25 cycles, followed by $10 \mathrm{~min}$ at $72^{\circ} \mathrm{C}$. Amplicons, separated on a $1 \%$ (wt/vol) agarose gel, were visualized under UV light. The housekeeping ubiquitin gene served as a control and the mRNA levels for each cDNA probe were normalized to the ubiquitin message RNA level. The real-time PCR was performed using the iCycler iQ Detection System (Bio-Rad Laboratories GmbH, Munich). The iQ SYBR Supermix (Bio-Rad Laboratories $\mathrm{GmbH}$ ) was used for PCR reactions according to the manufacturer's instructions in a final volume of $20 \mu \mathrm{l}$. The iCycler was programmed to $95^{\circ} \mathrm{C}$ for 2 min; 35 cycles of $95^{\circ} \mathrm{C}$ for $30 \mathrm{~s}, 55^{\circ} \mathrm{C}$ for $40 \mathrm{~s}$, and $72^{\circ} \mathrm{C}$ for 45 $\mathrm{s}$; and $72^{\circ} \mathrm{C}$ for $10 \mathrm{~min}$, followed by a melting curve program (55 to $95^{\circ} \mathrm{C}$ in increasing steps of $0.5^{\circ} \mathrm{C}$ ). The mRNA levels for each cDNA probe were normalized with respect to the actin/ ubiquitin message level. Fold induction values were calculated with the $\Delta \Delta \mathrm{CP}$ equation of Pfaffl (2001).

Primers used in the described gene expression experiments are shown in Table 2.

\section{$\mathrm{H}_{2} \mathrm{O}_{2}$ measurements.}

The $\mathrm{H}_{2} \mathrm{O}_{2}$ level was measured colorimetrically as described by Jana and Choudhuri (1982). $\mathrm{H}_{2} \mathrm{O}_{2}$ was extracted by homogenizing plant material with $2 \mathrm{ml}$ of phosphate buffer $(50 \mathrm{mM}$, $\mathrm{pH}$ 6.5), including $10 \mathrm{mM}$ 3-amino-1.2.4-triazole (Sigma, Germany). The homogenate was centrifuged at $6,000 \times g$ for 25 min at $4^{\circ} \mathrm{C}$. Extracted solution $(600 \mu \mathrm{l})$ was mixed with $200 \mu \mathrm{l}$ of $0.1 \%$ titanium sulfate (Sigma) in $20 \% \mathrm{H}_{2} \mathrm{SO}_{4}$ ( $\mathrm{vol} / \mathrm{vol}$ ) and the mixture was then centrifuged at $6,000 \times g$ for $15 \mathrm{~min}$ at $4^{\circ} \mathrm{C}$. Fluorescence was measured at $410 \mathrm{~nm}$ by using a TECAN SPECTRA fluorescence spectrophotometer (TECAN, Germany). Because the generated $\mathrm{H}_{2} \mathrm{O}_{2}$ is expected to correlate with the amount of BvGLP-1 expressed in pant cells, the $\mathrm{H}_{2} \mathrm{O}_{2}$ level was calculated on the basis of total protein quantified according to Bradford (1976).

\section{ACKNOWLEDGMENTS}

This work was financially supported by the Deutsche Forschungsgemeinschaft (grant nos. SFB167-A19 and SFB604-A7), the Bundesministerium für Bildung und Forschung, Germany (grant number 03152 31B), and DAAD (grant number D/08/01773 andD/08/01754).

\section{LITERATURE CITED}

Bateman, D. F., and Beer, S. V. 1965. Simultaneous production and synergistic action of oxalic acid and polygalacturonase during pathogenesis by Sclerotium rolfsii. Phytopathology 55:204-211.

Bernier, F., and Berna, A. 2001. Germins and germin-like proteins: Plant do-all proteins. But what do they do exactly? Plant Physiol. Biochem. 39:545-554.

Bradford, M. 1976. A rapid and sensitive method for the quantitation of microgram quantities of protein utilizing the principle of protein-dye binding. Anal. Biochem. 72:248-254. 
Broglie, K., Chet, I., Holliday, M., Cressman, R., Biddle, P., Knowlton, S. Mauvais, C. J., and Broglie, R. 1991. Transgenic plants with enhanced resistance to the fungal pathogen Rhizoctonia solani. Science 254:11941107.

Bütehorn, B., Rhody, D., Franken, P., 2000. Isolation and characterisation of Pitef1 encoding the translation elongation factor EF-1a of the root endophyte Piriformospora indica. Plant Biol. 49.687-692.

Cai, D., Kleine, M., Kifle, S., Harloff, H. J., Sandal, N. N., Marcker, K. A., Klein-Lankhorst, R. M., Salentijn, E. M. J., Lange, W., Stiekema, W. J., Wyss, U., Grundler, F. M. W. and Jung, C. 1997. Positional cloning of a gene for nematode resistance in sugar beet. Science 275:832-834.

Cai, D., Thurau, T., Weng, L. H., Wegelin, T., Tian, Y., Grundler, F. M W., and Jung, C. 2005. An enhanced expression of $H_{s} 1^{\text {pro-l }}$ in feeding sites is required for initiation of resistance to the beet cyst nematode (Heterodera schachtii Schmidt). Biol. Mol. Plant-Microbe Interact. 4:293-296.

Carter, C., and Thornburg, R. W. 1999. Germin-like proteins: Structure, phylogeny and function. J. Plant Biol. 42:97-108.

Chiriboga, J. 1966. Purification and properties of oxalic acid oxidase Arch. Biochem. Biophys. 116:516-523.

Christensen, A. B., Thordal-Christensen, H., Zimmermann, G., Gjetting, T., Lyngkjær, M. F., Dudler, R., and Schweizer, P. 2004. The germinlike protein GLP4 exhibits superoxide dismutase activity and is an important component of quantitative resistance in wheat and barley. Mol. Plant-Microbe Interact. 17:109-117.

Datta, K., Koukolikova-Nicola, Z., Baisakh, N., Oliva, N., and Datta, S. K. 2000. Agrobacterium-mediated engineering for sheath blight resistance of indica rice cultivars from different ecosystems. Theor. Appl. Genet. 100:832-839.

Deshmukh, S., Hückelhoven, R., Schäfer, P., Imani, J., Sharma, M., Weiss, M., Waller, F., and Kogel, K. H. 2006. The root endophytic fungus Piriformospora indica requires host cell death for proliferation during mutualistic symbiosis with barley. Proc. Natl. Acad. Sci. U.S.A. 103:18450-18457.

Donaldson, P. A., Anderson, T., Lane, B. G., Davidson, A. L., and Simmonds, D. H. 2001. Soybean plants expressing an active oligomeric oxalate oxidase from the wheat gf-2.8 (germin) gene are resistant to the oxalate-secreting pathogen Sclerotinia sclerotiorum. Physiol. Mol. Plant Pathol. 59:297-307.

Dong, X., Ji, R., Guo, X., Foster, S. J., Chen, H., Dong, C., Liu, Y., Hu, Q., and Liu, S. 2008. Expressing a gene encoding wheat oxalate oxidase enhances resistance to Sclerotinia sclerotiorum in oilseed rape (Brassica napus) Planta 228:331-340.

Druka, A., Kudrna, D., Kannangara, C. G., von Wettstein, D., and Kleinhofs, A. 2002. Physical and genetic mapping of barley (Hordeum vulgare) germin-like cDNAs. PNAS 99:850-855.

Dumas, B., Sailland, A., Cheviet, J. P., Freyssinet, G., and Pallett, K. 1993. Identification of barley oxalate oxidase as a germin-like protein. C. R. Acad. Sci. Ser. III Sci. Vie 316:793-798.

Epple, P. Apel, K., and Bohlmann, H. 1995. An Arabidopsis thaliana thionin gene is inducible via a signal transduction pathway different from that for pathogenesis-related proteins. Plant Physiol. 109:813-820.

Eynck, C., Koopmann, B., Grunewaldt-Stoecker, G., Karlovsky, P., and von Tiedemann, A. 2007. Differential interactions of Verticillium longisporum and $V$. dahliae with Brassica napus detected with molecular and histological techniques. Eur. J. Plant Pathol. 118:259-274.

Farmer, E. E., Johnson, R. R., and Ryan, C. A. 1992. Regulation of expression of proteinase inhibitor genes by methyl jasmonate and jasmonic acid. Plant Physiol. 98:995-1002.

Ferrari, S., Vairo, D., Ausubel, F. M., Cervone, F., and De Lorenzo, G. 2003. Tandemly duplicated Arabidopsis genes that encode polygalacturonase-inhibiting proteins are regulated coordinately by different signal transduction pathways in response to fungal infection. Plant Cell 15:93106

Gaffney, T., Friedrich, L., Vernooij, B., Negrotto, D., Nye, G., Uknes, S., Ward. E., Kessmann, H., and Ryals, J. 1993. Requirement of salicylic acid for the induction of systemic acquired resistance. Science 261:754-756.

Glazebrook, J. 2005. Contrasting mechanisms of defense against biotrophic and necrotrophic pathogens. Annu. Rev. Phytopathol. 43:205-227.

Godoy, G., Steadman, J. R., Dickman, M. B., and Dam, R. 1990. Use of mutants to demonstrate the role of oxalic acid in pathogenicity of Sclerotinia sclerotiorum on Phaseolus vulgaris. Physiol. Mol. Plant Pathol. 37:179-191.

Gundlach, H., Müller, M. J., Kuchan, T. M., and Zenk, M. H. 1992. Jasmonic acid is a signal transducer in elicitor-induced plant cell cultures. Proc. Natl. Acad. Sci. U.S.A. 89:2389-2393.

Hu, X., Bidney, D. L., Yalpani, N., Duvick, J. P., Crasta, O., Folkerts, O., and Lu, G. 2003. Overexpression of a gene encoding hydrogen peroxide-generating oxalate oxidase evokes defense responses in sunflower. Plant Physiol. 133:170-181.
Jana, S., and Choudhuri, M. A. 1982. Glycolate metabolism of three submersed aquatic angiosperms during ageing. Aquat. Bot. 12:345-354.

Keijer, J., Korsman, M. G., Dullemans, A. M., Houterman, P. M., de Bree, J., and Van Silfhout, C. H. 1997. In vitro analysis of host plant specificity in Rhizoctonia solani. Plant Pathol. 46:659-669.

Kesarwani, M., Azam, M., Natarajan, K., Mehta, A., and Datta, A. 2000. A Oxalate decarboxylase from Collybia velutipes molecular cloning and its overexpression to confer resistance to fungal infection in transgenic tobacco and tomato. J. Biol. Chem. 275:7230-7238.

Kloepper, J. W., Tuzun, S., and Kuc, J. A. 1992. Proposed definitions related to induced disease resistance. Biocontrol. Sci. Technol. 2:349-351.

Knop, W. 1860. Über die Ernährung der Pflanzen durch wasserige Lösungen unter Ausschluss des Bodens. Landwirtsch. Versuchsstat. 2:65-99, 270-293.

Koncz, C., and Schell, J. 1986. The promoter of TL-DNA gene 5 controls the tissue-specific expression of chimaeric genes carried by a novel type of Agrobacterium binary vector. Mol. Gen. Genet. 204:383-396.

Lane, B. G. 1994. Oxalate, germin, and the extracellular matrix of higher plants. FASEB (Fed. Am. Soc. Exp. Biol.) J. 5:294-301.

Li, J., Brader, G., and Palva, E. T. 2004. The WRKY70 transcription factor: A node of convergence for jasmonate-mediated and salicylate-mediated signals in plant defense. Plant Cell 16:319-331

Liang, H., Maynard, C. A., Allen, R. D., and Powell, W. A. 2001. Increased Septoria musiva resistance in transgenic hybrid poplar leaves expressing a wheat oxalate oxidase gene. Plant Mol. Biol. 45:619629.

Maddaloni, M., Forlani, F., Balmas, V., Donini, G., Stasse, L., Corazza, L., and Motto, M. 1997. Tolerance to the fungal pathogen Rhizoctonia solani AG4 of transgenic tobacco expressing the maize ribosome-inactivating protein b-32. Transgenic Res. 6:393-402.

Malamy, J., Carr, J. P., Klesslg, D. F., and Raskin, I. 1990. Salicylic acid: A likely endogenous signal in the resistance response of tobacco to viral infection. Science 250:1002-1004.

Membré, N., Bernier, F., Staiger, D., and Berna, A. 2000. Arabidopsis thaliana germin-like proteins: Common and specific features point to a variety of function. Planta 211:345-354.

Murashige, T., and Skoog, F. 1962. A revised medium for rapid growth and bioassays with tobacco tissue cultures. Physiol. Plant. 15:473-497.

Oelmüller, R., Peškan-Berghöfer, T., Shahollari, B., Sherameti, I., and Varma, A. 2005. MATH-domain containing proteins represent a novel gene family in Arabidopsis thaliana and are involved in plant/microbe interactions. Physiol. Plant. 124:152-166.

Olson, P. D., and Varner, J. E. 1993. Hydrogen peroxide and lignifications. Plant J. 4:887-892.

Penninckx, I. A. M. A., Eggermont, K., Terras, F. R. G., Thomma, B. P. H J., Samblanx, G. W. D., Buchala, A., Metraux, J. P., Manners, J. M., and Broekaert, W. F. 1996. Pathogen-induced systemic activation of a plant defensin gene in Arabidopsis follows a salicylic acid-independent pathway. Plant Cell 8:2309-2323.

Perl-Treves, R., Foley, R. C., Chen W., and Singh, K. B. 2004. Early induction of the Arabidopsis GSTF8 promoter by specific strains of the fungal pathogen Rhizoctonia solani. Mol. Plant-Microbe Interact. 17:70-80

Peškan-Berghöfer, T., Shahollari, B., Giang, P. H., Hehl, S., Markert, C., Blanke, V., Varma, A. K., and Oelmüller, R. 2004. Association of Piriformospora indica with Arabidopsis thaliana roots represents a novel system to study beneficial plant-microbe interactions and involves early plant protein modifications in the endoplasmatic reticulum and at the plasma membrane. Physiol. Plant. 122:465-477.

Pfaffl, M. W. 2001. A new mathematical model for relative quantification in real-time RT-PCR. Nucleic Acids Res. 29:e45.

Pieterse, C. M. J., van Wees, S. C. M., Hoffland, E., van Pelt, J. A., and van Loon, L. C. 1996. Systemic resistance in Arabidopsis induced by biocontrol Bacteria is independent of salicylic acid accumulation and pathogenesis-related gene expression Plant Cell 8:1225-1237.

Piffanelli, P., Zhou, F. S., Casais, C., Orme, J., Jarosch, B., Schaffrath, U., Collins, N. C., Panstruga, R., and Schulze-Lefert, P. 2002. The barleyMLO modulator of defense and cell death is responsive to biotic and abiotic stress stimuli. Plant Physiol. 129:1076-1085.

Potter, S., Uknes, S., Lawton, K., Winter, A., Chandler, D., DiMaio, J., Novitzky, R., Ward, E., and Ryals, J. 1993. Regulation of a hevein-like gene in Arabidopsis. Mol. Plant-Microbe Interact. 6:680-685.

Ramputh, A. I., Arnason, J. T., Cass, L., and Simmonds, J. A. 2002. Reduced herbivory of the European corn borer (Ostrinia nubilalis) on corn transformed with germin, a wheat oxalate oxidase gene. Plant Sci. $162: 431-440$

Ross, A. F. 1961. Localized acquired resistance to plant virus infection in hypersensitive hosts. Virology 14:329-339.

Samuelian, S., Kleine, M., Ruyter-Spira, C. P., Klein-Lankhorst, R. M., and Jung, C. 2004. Cloning and functional analyses of a gene from 
sugar beet up-regulated upon cyst nematode infection Plant Mol. Biol. 54:147-156.

Schweizer, P., Christoffel, A., and Dudler, R. 1999. Transient expression of members of the germin-like gene family in epidermal cells of wheat confers disease resistance. Plant J. 20:541-552.

Steventon, L. A., Okori, P., and Dixelius, C. 2001. An investigation of the susceptibility of Arabidopsis thaliana to isolates of two species of Verticillium. J. Phytopathol. 149:395-401.

Stone, H. E., and Armentrout, V. N. 1985. Production of oxalic acid by Sclerotium cepivorum during infection of onion. Mycologia 77:526530

Thomma, B., Eggermont, K., Penninck, I., Mauch-Mani, B., Vogelsang, R., Cammue, B. P. A., and Broekaert, W. F. 1998. Separate jasmonate dependent and salicylate-dependent defense-response pathways in Arabidopsis are essential for resistance to distinct microbial pathogens. PNAS 95:15107-15111.

Thompson, C., Dunwell, J. M., Johnstone, C. E., Lay, V., Schmitt, M., Watson, H., and Nisbet, G. 1995. Degradation of oxalic acid by transgenic oilseed rape plants expressing oxalate oxidase. Euphytica 85:169-172.

Thordal-Christensen, H., Zhang, Z., Wei, Y., and Collinge, D. B. 1997 Subcellular localization of $\mathrm{H}_{2} \mathrm{O}_{2}$ in plants. $\mathrm{H}_{2} \mathrm{O}_{2}$ accumulation in papillae and hypersensitive response during the barley-powdery mildew interaction. Plant J. 11:1187-1194.

Thurau, T., Kifle, S., Jung, C., and Cai, D. 2003. The promoter of the nematode resistance gene $H s 1^{\text {pro-l }}$ activates a nematode-responsive and feeding site-specific gene expression in sugar beet (Beta vulgaris L.) and Arabidopsis thaliana. Plant Mol. Biol. 52:643-660.

Vadassery, J., Tripathi, S., Prasad, R., Varma, A., and Oelmueller, R. 2009. Monodehydroascorbate reductase 2 and dehydroascorbate reductase 5 are crucial for a mutualistic interaction between Piriformospora indica and Arabidopsis. J. Plant Physiol. 166:1263-1274

Vallelian, B. L., Mosinger, E., Metraux, J. P., and Schweizer, P. 1998. Structure, expression and localization of a germin-like protein in barley (Hordeum vulgare L.) that is insolubilized in stressed leaves. Plant Mol. Biol. 37:297-308.

Valvekens, D., Van Montagu, M., and Van Lijsebettens, M. 1988. Agrobacterium tumefaciens-mediated transformation of Arabidopsis thaliana root explants by using kanamycin selection. Proc. Natl. Acad. Sci. U.S.A. 85:5536-5540.

Van Baarlen, P., Woltering, E. J., Staats, M., and van Kan, J. A. L. 2007. Histochemical and genetic analysis of host and non-host interactions of Arabidopsis with three Botrytis species: An important role for cell death control. Mol. Plant Pathol. 8:41-54.

Varma, A., Verma, S., Sudha, Sahay, N. S., Butehorn, B., and Franken, P.
1999. Piriformospora indica, a cultivable plant growth promoting root endophyte. Appl. Environ. Microbiol. 65:2741-2744.

Veronese, P., Narasimhan, M. L., Stevenson, R. A., Zhu, J. K., Weller, S. C., Subbarao, K. V., and Bressan, R. A. 2003. Identification of a locus controlling Verticillium disease symptom response in Arabidopsis thaliana. Plant J. 35:574-587.

Ward, E. R., Uknes, S. J., Williams, S. C., Dincher, S. S., Wiederhold, D. L., Alexander, D. C., Ahl-Goy, P., Métraux, J.-P., and Ryals, J. A. 1991. Coordinate gene activity in response to agents that induce systemic acquired resistance. Plant Cell 3:1085-1094.

Wei, Y. D., Zhang, Z. G., Andersen, C. H., Schmelzer, E., Gregersen, P. L., Collinge, D. B., Smedegaard-Petersen, V., and Thordal-Christensen, H. 1998. An epidermis/papilla-specific oxalate oxidase-like protein in the defense response of barley attacked by the powdery mildew fungus. Plant Mol. Biol. 36:101-112.

Woo, E. J., Dunwell, J. M., Goodenough, P. W., Marvier, A. C., and Pickersgill, R. W. 2000. Germin is a manganese containing homohexamer with oxalate oxidase and superoxide dismutase activities. Nat. Struct. Biol. 7:1036-1040.

Wu, S., Druka, A., Horvath, H., Kleinhofs, A., Kannangara, C. G., and Wettstein, D. 2000. Functional characterization of seed coat-specific members of the barley germin gene family. Plant Physiol. Biochem. 38:685-698.

Zaghmout, O. F., Dang, P. D., and Allen, R. D. 1997. Expression of oxalate oxidase in transgenic plants provides resistance to oxalic acid and oxalate producing fungi. Plant Physiol. Suppl. Plant Physiol. 114:227.

Zeise, K. 1992. Gewächshaustest zur Resistenzprüfung von Winterraps (Brassica napus L. var. oleifera Metzger) gegen den Erreger der Rapswelke Verticillium dahliae Kleb. Nachrichtenbl Deutscher Pflanzenschutzd 44:125-128.

Zeise, K., and von Tiedemann, A. 2002. Host specialization among vegetative compatibility groups of Verticillium dahliae in relation to Verticillium longisporum. J. Phytopathol. 150:112-119.

Zhang, Z., Collinge, D. B., and Thordal-Christensen, H. 1995. Germin-like oxalate oxidase, a $\mathrm{H}_{2} \mathrm{O}_{2}$-producing enzyme, accumulates in barley attacked by the powdery mildew fungus. Plant J. 8:139-145.

Zhou, F., Zhang, Z., Gregersen, .P. L., Mikkelsen, J. D., de Neergaard, E., Collinge, D. B., and Thordal-Christensen, H. 1998. Molecular characterization of the oxalate oxidase involved in the response of barley to the powdery mildew fungus. Plant Physiol. 117:33-41.

Zimmermann, G., Bäumlein, H., Mock, H. P., Himmelbach, A., and Schweizer, P. 2006. The multigene family encoding germin-like proteins of barley. Regulation and function in basal host resistance. Plant Physiol. 142:181-192. 